\title{
An Analysis of Interspecific Hybrids and Phylogenetic Implications ${ }^{1}$ in Cucumis (Cucurbitaceae)
}

\author{
By
}

\author{
A. K. Singh and K. S. Yadava
}

(Received April 9, 1984)

Key Words: Angiosperms, Cucurbitaceae, Cucumis.-Interspecific crossability, chromosome pairing, pollen fertility, phylogenetic relationship, karyomorphology.

Abstract: Investigations on interspecific crossability in 8 Cucumis species $(2 \mathrm{n}=24)$ and chromosome pairing and pollen fertility of their hybrids from 15 combinations have been utilized for tracing the phylogenetic relationships among these taxa and factors responsible for their differentiation. A collective evaluation of data suggests that there are three broad groups of species, one of the spiny fruited interfertile species, whose hybrids show varying degree of chromosome associations and low to high pollen fertility; the second of species with non-spiny fruits, which are completely incompatible with the former but weakly compatible with the cultivated species, $C$. melo L. to produce partly developed seeds, and the third group of C. metuliferus E. MEY. ex SchraD. and C. melo and its different botanical varieties. The species with spiny fruits can be further divided based on karyomorphological similarities and/or on relative genomic affinity, indicated by chromosome pairing and hybrid pollen fertility.

Morphological and karyomorphological investigations in the genus Cucumis L. indicated South African annual species as primitive and identified 5 distinct groups in taxa with $2 \mathrm{n}=24$ (YADAV \& SinGH 1984). The crossability studies, chromosome pairing and pollen fertility in $F_{1}$ hybrids are useful in assessing species relationships and phylogeny. The genus Cucumis has 30 species divided into two groups on base number (JEFFERY 1980). Hybridization between C. hardwickii RoYLE $(2 \mathrm{n}=14)$ and $C$. sativus L. $(2 \mathrm{n}=14)$ of Indian origin was reported by IMAzu \& Fuishita (1956) and Deakin \& al. (1971), who concluded a close phylogenetic relationship between the two. In the larger group of species

1 Cytogenetics in Cucumis III. 
with $2 \mathrm{n}=24$ which are distributed in South and East Africa, a series of reports on interspecific hybridization are available without comprehensive and conclusive evidences on phylogeny (WHITAKER 1933; BATRA 1953; Smith \& Venkat Ram 1954; Deakin \& al. 1971; Norton 1969; ANDRUS \& FASSULIOTIS 1965; Kroon \& al. 1979; Dane \& al. 1980; Nus \& Oost 1980; KHo \& al. 1980). DeAKIN \& al. (1971) were the first to produce a comprehensive and monographic account on relative cross compatibility between these species and pollen fertility of their $F_{1}$ hybrids, involving 14 species including cultivated C. melo $\mathrm{L}$. Based on these data they grouped Cucumis species into four major groups. Recently DANE \& al. (1980) have provided additional data on chromosome associations in $F_{1}$ hybrids of 6 diploid species $(2 n=24)$ and discussed phylogeny of these species.

The present paper reports data on crossability between 8 diploid species $(2 \mathrm{n}=24)$ including $C$. melo in 33 combinations. Chromosome pairing and pollen fertility of 15 successful interspecific hybrids along with crossability have been utilized for tracing relative phylogenetic affinities among these taxa.

The phytogeographical, phytochemical and karyological data (ReHM 1960, Brown \& al. 1969; Yadava \& Singh 1984) in relation to the taxa studied, and others have also been discussed for comprehensive and rational conclusions.

\section{Material and Methods}

Identities and sources of Cucumis wild species used have been summarised in Table 1. The seeds were sown in small beds in the Botanical Garden, University of Jodhpur, Jodhpur, under normal rainy season.

Anthesis occurs around an hour before sunrise and anthers dehisce soon after. Stigma is receptive upto 4 hours after anthesis. Healthy female flower buds, a day before anthesis were bagged with butter paper. The following morning the stigmas were dusted with pollen from the desired male parent using sterilized mounted needles. Two days later bags were either removed or punched to facilitate proper development of the fruits.

For cytological analysis young flower buds were collected and fixed in (1:3) acetic alcohol containing a drop of $5 \%$ ferric chloride. Anthers were squashed in $1 \%$ acetocarmine. Temporary preparations were used for detailed analysis and photography. Pollen grains were stained in $1 \%$ acetocarmine and stained pollen grains were counted fertile.

The chromosome associations in $F_{1}$ hybrids were analysed statistically by one way analysis of variance programme over computer.

\section{Results}

Hybridizations were made in 33 combinations involving 8 taxa including the cultivated taxon C. melo var. momordica (Table 2). Hybrids could be established only in 15 combinations (Table 3 ). Except with the 
Table 1. Taxonomic status and sources of Cucumis species. $A=$ Annual. $\mathbf{P}=$ Perennial. DDR $=$ Deutsche Demokratische Republik $(=$ German Democra tic Republic)

\begin{tabular}{|c|c|c|c|c|c|}
\hline Species & Habit & $\begin{array}{l}\text { Fruit } \\
\text { Surface }\end{array}$ & Source & Coll. No. & Origin \\
\hline $\begin{array}{l}\text { C. melo var. momordica } \\
\text { Cogn. }\end{array}$ & A & Smooth & India & - & S. Africa \\
\hline $\begin{array}{l}\text { C. dipsaceus EHRENB. } \\
\text { ex SPACH }\end{array}$ & A & $\begin{array}{l}\text { Soft- } \\
\text { Spined }\end{array}$ & DDR & CUC 14/76 & Ethiopia \\
\hline $\begin{array}{l}\text { C. anguria L. var. } \\
\text { anguria MEEuse }\end{array}$ & A & Spined & DDR & CUC9E 74 & $\begin{array}{l}\text { S. America } \\
\text { Introduction }\end{array}$ \\
\hline $\begin{array}{l}\text { C. anguria } \mathrm{L} \text {. var. } \\
\text { longipus MeEusE }\end{array}$ & A & Spined & DDR & $\begin{array}{l}\text { CUC } \\
27 \mathrm{E} 74\end{array}$ & S. Rhodesia \\
\hline C. myriocarpus NAUD. & $\mathrm{A}$ & Spined & DDR & $\mathrm{CUC} 31 / 74$ & S. W. Africa \\
\hline C. zeyheri Sond. & $\mathrm{P}$ & Spined & DDR & $\begin{array}{l}\text { CUCU } \\
416 / 765\end{array}$ & S. Africa \\
\hline C. prophetarum L.f. & $\mathrm{P}$ & Spined & India & - & Sudan, Egypt \\
\hline C. species & $\mathrm{P}$ & Spined & DDR & $\begin{array}{l}\text { CUCU } \\
44 / 74\end{array}$ & \\
\hline
\end{tabular}

Table 2. Number of pollinations (A) and fruit set (B) in crosses between Cucumis species $(2 \mathrm{n}=24)$. NA $=$ Not attempted. ()$=$ Figures in brackets indicate seeds inviable, hybrid not established

\begin{tabular}{|c|c|c|c|c|c|c|c|c|}
\hline$\delta$ Parent & 1 & 2 & 3 & 4 & 5 & 6 & 7 & 8 \\
\hline Q Parent & $\mathrm{A} / \mathrm{B}$ & $\mathrm{A} / \mathrm{B}$ & $\mathrm{A} / \mathrm{B}$ & $\mathrm{A} / \mathrm{B}$ & $\mathrm{A} / \mathrm{B}$ & $\mathrm{A} / \mathrm{B}$ & $\mathrm{A} / \mathrm{B}$ & $\mathrm{A} / \mathrm{B}$ \\
\hline 1. C. dipsaceus & - & $12 / 5$ & $6 / 3$ & $16 / 0$ & NA & $18 / 5$ & $20 / 4$ & $5 / 0$ \\
\hline 2. C. myriocarpus & $11 / 0$ & - & $7 / 0$ & $24 / 2$ & $\mathrm{NA}$ & $10 / 0$ & NA & $\mathrm{NA}$ \\
\hline 3. C. zeyheri & $5 / 0$ & $5 / 2$ & - & $20 /(3)$ & $\mathrm{NA}$ & $4 / 2$ & $\mathrm{NA}$ & $\mathrm{NA}$ \\
\hline 4. C. prophetarum & $15 / 6$ & NA & $20 / 10$ & - & $2 / 2$ & $6 / 3$ & $15 / 11$ & $5 /(3)$ \\
\hline 5. Accession CUCU 44/74 & NA & NA & NA & $8 / 0$ & - & NA & NA & NA \\
\hline 6. C. anguria var. longipus & $31 / 0$ & $30 / 13$ & $11 / 5$ & $42 / 4$ & NA & - & $40 / 18$ & $12 / 0$ \\
\hline 7. C. anguria var. anguria & $12 / 0$ & NA & NA & $3 / 0$ & $\mathrm{NA}$ & $30 / 7$ & - & NA \\
\hline 8. C. melo var. momordica & $20 / 0$ & NA & NA & $10 / 0$ & $\mathrm{NA}$ & $15 / 0$ & NA & - \\
\hline
\end{tabular}


Table 3. Comparative morphology of Cucumis species and their $\mathrm{F}_{1}$ hybrids. $\mathrm{L}=$ Length, Ser $=$ Serrate, Ent $=$ Entire, SSSp. $=$ Short Sparse Spine, LSSp. $=$ Long Sparse Spine,

Dense Spine, Str $=$

\begin{tabular}{|c|c|c|c|c|c|}
\hline \multirow{3}{*}{ Species/Cross } & \multicolumn{5}{|c|}{ Leaf } \\
\hline & \multicolumn{2}{|c|}{ Size in $\mathrm{cm}$} & \multirow[t]{2}{*}{ Shape } & \multirow[t]{2}{*}{ Apex } & \multirow[t]{2}{*}{ Margin } \\
\hline & $\mathbf{L}$ & W & & & \\
\hline C. dipsaceus & 8.5 & 8.1 & Spathulate & $\mathrm{Ob}$ & Ser \\
\hline C. myriocarpus & 4.1 & 5.5 & $\mathrm{Pl}, 5-7 \mathrm{lob}$ & $\mathrm{Ob}$ & Ent \\
\hline C. zeyheri & 10.3 & 9.4 & Pl, 5-7 lob & $\mathrm{Ac}$ & Ser \\
\hline C. prophetarum & 4.5 & 6.2 & $\mathrm{P} 1,5-7$ lob & Acu & Ser \\
\hline C. anguria var. longipus & 9.7 & 10.9 & $\mathrm{Pl}, 5-7 \mathrm{lob}$ & Ac & Ser \\
\hline C. anguria var. anguria & 8.8 & 10.7 & $\mathrm{Pl}, 5-7$ lob & $\mathrm{Acu}$ & Ent \\
\hline Collection CUCU $44 / 74$ & 3.5 & 3.7 & $\mathrm{Pl}, 5-7$ lob & Ac & Ser \\
\hline C. dipsaceus $\times$ C. zeyheri & 5.5 & 6.8 & $\mathrm{Pl}, 5-7$ lob & $\mathrm{Ac}$ & Ser \\
\hline C. dipsaceus $\times$ C. myriocarpus & 6.6 & 9.2 & $\mathrm{Pl}, 5$ lob & $\mathrm{Ob}$ & Ser \\
\hline C. prophetarum $\times C$. dipsaceus & 5.5 & 6.5 & $\mathrm{Pl}, 3-5$ lob & Acu & Ser \\
\hline $\begin{array}{l}\text { C. dipsaceus } \times \text { C. anguria } \\
\text { var. longipus }\end{array}$ & 8.2 & 10.1 & $\mathrm{Pl}, 3-5 \mathrm{lob}$ & $\mathrm{Ac}$ & Ser \\
\hline $\begin{array}{l}\text { C. dipsaceus } \times C \text {. anguria } \\
\text { var. anguria }\end{array}$ & 75 & & & & \\
\hline C. myriocarpus $\times$ C. prophetarum & $\begin{array}{l}1.2 \\
4.2\end{array}$ & $\begin{array}{l}7.1 \\
4.8\end{array}$ & $\begin{array}{l}\mathrm{Pl}, 5 \mathrm{lob} \\
\mathrm{Pl}, 5-7 \mathrm{lob}\end{array}$ & $\begin{array}{l}\text { Acu } \\
\mathrm{Acu}\end{array}$ & $\begin{array}{l}\text { Ser } \\
\text { Ent }\end{array}$ \\
\hline C. zeyheri $\times$ C. myriocarpus & 4.2 & 3.7 & $\mathrm{Pl}, 3-5 \mathrm{lob}$ & $\mathrm{Ac}$ & Ser \\
\hline $\begin{array}{l}\text { C. prophetarum } \times \text { C. zeyheri } \\
\text { C. zeyheri } \times C \text {. anguria }\end{array}$ & 3.9 & 5.0 & Pl, 3-5 lob & Acu & Ser \\
\hline $\begin{array}{l}\text { var. longipus } \\
\text { C. prophetarum } \times \text { Collection }\end{array}$ & 7.3 & 8.3 & $\mathrm{Pl}, 5-7 \mathrm{lob}$ & $\mathrm{Ac}$ & Ser \\
\hline $\begin{array}{l}\text { CUCU } 44 / 74 \\
\text { C. prophetarum } \times C \text {. anguria }\end{array}$ & 5.3 & 5.2 & $\mathrm{Pl}, 5 \mathrm{lob}$ & $\mathrm{Ac}$ & Ser \\
\hline $\begin{array}{l}\text { var. longipus } \\
\text { C. anguria var. longipus } \times\end{array}$ & 5.5 & 6.3 & $\mathrm{Pl}, 5-7 \mathrm{lob}$ & $\mathrm{Ac}$ & Ser \\
\hline $\begin{array}{l}\text { C. prophetarum } \\
\text { C. prophetarum } \times \text { C. anguria }\end{array}$ & 6.3 & 7.2 & Pl, 5-7 lob & Ac & Ser \\
\hline C. anguria var. longipus $\times$ & 5.4 & 6.2 & $\mathrm{P} 1,5-7$ lob & Acu & Ser \\
\hline $\begin{array}{l}\text { C. anguria var. anguria } \\
\text { C. anguria var. anguria } \times\end{array}$ & 6.9 & 9.5 & $\mathrm{Pl}, 5-7$ lob & $\mathrm{Ac}$ & Ser \\
\hline C. anguria var. longipus & 7.2 & 8.5 & $\mathrm{Pl}, 5-7$ lob & Acu & Ent \\
\hline
\end{tabular}

non-spiny fruited cultivated taxon, C. melo var. momordica, the spiny fruited species were cross compatible with each other in one or the other direction. There were differences in reciprocal crossability. C. prophe tarum produced fruits with immature seeds when $C$. melo var. momordica used as a male parent. $C$. anguria var. longipus $\times C$. anguria var. anguria and $C$. anguria var. longipus $\times C$. prophetarum were the two combinations in which the hybrids could be established in both the directions (Table 3). 
$\mathrm{W}=$ Width, $\mathrm{Pl}=$ Palmate, $\mathrm{Lob}=$ Lobed, $\mathrm{Acu}=$ Acuminate, $\mathrm{Ac}=$ Acute, $\mathrm{Ob}=$ Obtuse, LDSp. $=$ Long Dense Spine, TSSSp. $=$ Thin Soft Sparse Spine, TSDSp. $=$ Thin Soft Striped, Unstr $=$ Unstriped

\begin{tabular}{|c|c|c|c|c|c|c|}
\hline \multicolumn{4}{|c|}{ Flower (size in $\mathrm{cm}$ ) } & \multicolumn{3}{|c|}{ Fruit } \\
\hline \multicolumn{2}{|c|}{ Female } & \multicolumn{2}{|c|}{ Male } & \multicolumn{2}{|c|}{ Size in $\mathrm{cm}$} & \multirow[t]{2}{*}{ Surface } \\
\hline $\mathbf{L}$ & W & & W & $\mathrm{L}$ & W & \\
\hline 1.3 & 1.7 & 1.6 & 1.4 & 6.7 & 4.8 & TSSSp., Unstr \\
\hline 1.2 & 1.3 & 1.5 & 1.0 & 2.3 & 2.0 & SSSp., Str \\
\hline 1.1 & 2.0 & 2.2 & 1.3 & 5.0 & 3.5 & LDŚp., Str \\
\hline 1.3 & 1.2 & 2.1 & 1.2 & 4.1 & 3.3 & SSSp., Str \\
\hline 2.0 & 1.7 & 0.9 & 1.6 & 4.2 & 3.6 & LSSp., Unstr \\
\hline 2.2 & 1.3 & 1.1 & 1.4 & 5.5 & 4.3 & SSSp., Unstr \\
\hline 1.1 & 0.9 & 1.7 & 1.1 & 3.8 & 3.1 & SSSSp., Str \\
\hline 1.5 & 1.8 & 2.1 & 1.4 & 2.2 & 1.4 & TSSSp., Str \\
\hline 0.8 & 1.0 & 1.3 & 1.5 & 1.8 & 1.4 & TSDSp., Str \\
\hline 1.1 & 1.5 & 1.0 & 0.5 & 2.0 & 1.4 & TSDSp., Unstr \\
\hline 1.0 & 1.6 & 2.0 & 1.8 & 2.0 & 1.6 & TSDSp., Unstr \\
\hline 2.1 & 1.5 & 2.2 & 1.8 & 1.8 & 1.2 & TSDSp., Unstr \\
\hline 0.9 & 0.7 & 1.5 & 1.3 & 3.2 & 2.0 & LSSp., Unstr \\
\hline 1.0 & 1.3 & 1.0 & 0.9 & 2.0 & 1.7 & SSSp., Str \\
\hline 1.1 & 0.8 & 1.2 & 0.8 & 3.3 & 2.4 & LDSp., Str \\
\hline 0.7 & 1.2 & 1.8 & 1.3 & 4.8 & 3.1 & LDSp., Unstr \\
\hline 0.9 & 0.4 & 2.0 & 1.8 & 2.0 & 1.1 & SSSp., Str \\
\hline 0.6 & 0.8 & 1.7 & 1.2 & 2.1 & 1.6 & SSSp., Unstr \\
\hline 1.1 & 1.0 & 1.3 & 1.2 & 1.8 & 1.4 & LSSp., Unstr \\
\hline 0.7 & 0.3 & 1.5 & 1.0 & 1.8 & 1.3 & SSSp., Str \\
\hline 1.9 & 1.1 & 1.8 & 1.2 & 1.9 & 1.3 & LSSp., Unstr \\
\hline 2.0 & 1.2 & 1.2 & 1.3 & 1.5 & 1.1 & LSSp., Unstr \\
\hline
\end{tabular}

Morphology. A comparative account of morphological features of parents and their $F_{1}$ hybrids have been summarised in Table 3. The characters such as lobing of leaves, acute leaf apex over acuminate, and acuminate leaf apex over obtuse; serrate margin of leaves, and long dense spines on the fruit surface wherever present in a cross combination were expressed in $\mathrm{F}_{1}$ hybrids, and hence are dominant. Breeding behaviour of striping of fruits was inconsistent. In $C$. dipsaceus $\times C$. myriocarpus the 
Table 4. Chromosomal association and chiasma frequency at $\mathrm{MI}$ in $\mathrm{F}_{1}$ hybrids of $\mathrm{Cucumis}$ C. dipsaceus hybrids differ at $5 \%$ level of significance from rest. Mean ring bivalent

Cross

No. of univalents Range Mean

C. dipsaceus $\times$ C. zeyheri

$0-24 \quad 3.04$

C. dipsaceus $\times$ C. myriocarpus $\pm 0.95$

C. dipsaceus $\times$ C. anguria var. longipus

$0-12 \quad 4.86$

C. dipsaceus $\times$ C. anguria var. anguria

$0-9 \quad 3.88$

$0-24$

C. prophetarum $\times$ C. dipsaceus

C. prophetarum $\times$ C. zeyheri

C. prophetarum $\times$ Collection CUCU $44 / 74$

C. prophetarum $\times$ C. anguria var. longipus

$\pm 0.53$

$0-10 \quad 2.2$

$\begin{array}{ll}0-4 & \pm 0.53 \\ 0 & 1.0\end{array}$

C. prophetarum $\times$ C. anguria var. anguria

$\begin{array}{ll} & \pm 0.27 \\ 0-8 & 1.98\end{array}$

C. myriocarpus $\times$ C. prophetarum

$0-6 \quad \pm 0.39$

C. zeyheri $\times$ C. myriocarpus

$\begin{array}{cc}0-6 & 2.0 \\ & \pm 0.39\end{array}$

$0-5 \quad 1.84$

$0-8$ $\pm 0.35$

C. zeyheri $\times$ C. anguria var. longipus

$0-2$

1.32 $\pm 0.35$

C. anguria var. longipus $\times$ C. prophetarum $\begin{array}{lc} & \pm 0.16 \\ 0-8 & 2.96\end{array}$

0.28

C. anguria var. longipus $\times C$. anguria var. anguria

0 $\pm 0.45$

C. anguria var. anguria $\times$ C. anguria var. longipus

$\begin{array}{cc}0-4 & 0.24 \\ & \pm 0.10 \\ 0 & 0\end{array}$

striping of fruits of the male parent was expressed in $F_{1}$ hybrid, but not in the crosses, $C$. zeyheri $\times C$. anguria var. longipus and $C$. prophetarum $\times C$. anguria var. longipus although it was a feature of the female parents. In certain crosses the maternal feature was expressed in the $F_{1}$ (Table 3 ). Quantitative characters such as leaf size and flower size were expressed as intermediate between the parents.

Cytology. All the parent species and 15 established $F_{1}$ hybrids were analysed cytologically for chromosome pairing, chiasma frequency, 
species. 25 PMCs were analysed in each combination. Mean univalent and bivalent in in $C$. anguria var. longipus hybrids differ at $5 \%$ level of significance from rest

\begin{tabular}{|c|c|c|c|c|c|c|c|c|}
\hline \multicolumn{4}{|c|}{ No. of bivalents } & \multirow{2}{*}{\multicolumn{2}{|c|}{$\begin{array}{c}\text { No. of } \\
\text { multivalents }\end{array}$}} & \multirow{2}{*}{\multicolumn{2}{|c|}{$\begin{array}{c}\text { No. of } \\
\text { chiasma/PMC }\end{array}$}} & \multirow{3}{*}{$\begin{array}{l}\text { Chiasm } \\
\text { Termi- } \\
\text { nalisatic } \\
\text { Coefficie }\end{array}$} \\
\hline \multicolumn{2}{|c|}{ Ring } & \multicolumn{2}{|c|}{ Rod } & & & & & \\
\hline Range & Mean & Range & Mean & Range & Mean & Range & Mean & \\
\hline $0-11$ & $\begin{array}{r}8.92 \\
\pm 0.31\end{array}$ & $0-4$ & $\begin{array}{l}1.2 \\
\pm 0.21\end{array}$ & $0-2$ & $\begin{array}{l}0.18 \\
\pm 0.08\end{array}$ & $0-24$ & $\begin{array}{l}21.8 \\
\pm 0.98\end{array}$ & 0.93 \\
\hline $5-12$ & $\begin{array}{r}8.76 \\
\pm 0.41\end{array}$ & $0-2$ & $\begin{array}{c}0.64 \\
\pm 0.12\end{array}$ & $0-1$ & $\begin{array}{c}0.12 \\
\pm 0.06\end{array}$ & $11-24$ & $\begin{array}{l}18.32 \\
\pm 0.54\end{array}$ & 0.97 \\
\hline $8-11$ & $\begin{array}{r}9.22 \\
\pm 0.23\end{array}$ & $0-4$ & $\begin{array}{c}0.84 \\
\pm 0.18\end{array}$ & 0 & 0 & $16-22$ & $\begin{array}{l}17.45 \\
\pm 0.41\end{array}$ & 0.96 \\
\hline $0-11$ & $\begin{array}{l}7.2 \\
\pm 0.22\end{array}$ & $0-3$ & $\begin{array}{l}1.66 \\
\pm 0.15\end{array}$ & $0-2$ & $\begin{array}{l}0.8 \\
\pm 0.05\end{array}$ & $0-24$ & $\begin{array}{l}19.66 \\
\pm 0.88\end{array}$ & 0.95 \\
\hline $7-12$ & $\begin{array}{r}8.68 \\
\pm 0.37\end{array}$ & $1-4$ & $\begin{array}{l}1.88 \\
\pm 0.17\end{array}$ & $\begin{array}{l}0-2 \\
\pm 0.08\end{array}$ & 0.14 & $\begin{array}{l}11-23 \\
\pm 0.52\end{array}$ & 20.84 & 0.95 \\
\hline $7-11$ & $\begin{array}{l}9.8 \\
\pm 0.37\end{array}$ & $1-3$ & $\begin{array}{l}1.4 \\
\pm 0.21\end{array}$ & $0-2$ & $\begin{array}{l}0.20 \\
\pm 0.07\end{array}$ & $16-22$ & $\begin{array}{l}18.36 \\
\pm 0.44\end{array}$ & 0.93 \\
\hline $6-11$ & $\begin{aligned} & 9.68 \\
\pm & 0.21\end{aligned}$ & $1-3$ & $\begin{array}{l}1.32 \\
\pm 0.32\end{array}$ & 0 & 0 & $15-23$ & $\begin{array}{l}17.8 \\
\pm 0.63\end{array}$ & 0.92 \\
\hline $8-11$ & $\begin{array}{l}10.08 \\
\pm 0.19\end{array}$ & $0-2$ & $\begin{array}{c}0.80 \\
\pm 0.13\end{array}$ & $0-1$ & $\begin{array}{l}0.06 \\
\pm 0.07\end{array}$ & $16-23$ & $\begin{array}{l}21.36 \\
\pm 0.39\end{array}$ & 0.96 \\
\hline $7-12$ & $\begin{array}{r}9.24 \\
\pm 0.28\end{array}$ & $0-2$ & $\begin{array}{l}1.6 \\
\pm 0.13\end{array}$ & $0-1$ & $\begin{array}{c}0.12 \\
\pm 0.06\end{array}$ & $15-24$ & $\begin{array}{l}21.84 \\
\pm 0.47\end{array}$ & 0.92 \\
\hline $5-12$ & $\begin{array}{l}9.8 \\
\pm 0.32\end{array}$ & $0-4$ & $\begin{array}{l}1.2 \\
\pm 0.19\end{array}$ & $0-2$ & $\begin{array}{l}0.2 \\
\pm 0.11\end{array}$ & $18-24$ & $\begin{array}{l}21.36 \\
\pm 0.34\end{array}$ & 0.90 \\
\hline $9-11$ & $\begin{array}{l}10.6 \\
\pm 0.19\end{array}$ & $0-3$ & $\begin{array}{l}1 \\
\pm 0.32\end{array}$ & $0-1$ & $\begin{array}{c}0.10 \\
\pm 0.12\end{array}$ & $21-23$ & $\begin{array}{l}21.12 \\
\pm 0.29\end{array}$ & 0.98 \\
\hline $8-11$ & $\begin{array}{l}8.8 \\
\pm 0.24\end{array}$ & $0-3$ & $\begin{array}{l}1.7 \\
\pm 0.20\end{array}$ & 0 & 0 & $15-22$ & $\begin{array}{l}21.32 \\
\pm 0.34\end{array}$ & 0.98 \\
\hline $9-12$ & $\begin{array}{l}10.68 \\
\pm 0.22\end{array}$ & $1-3$ & $\begin{array}{c}1.04 \\
\pm 0.17\end{array}$ & $0-2$ & $\begin{array}{c}0.12 \\
\pm 0.11\end{array}$ & $17-23$ & $\begin{array}{l}22.76 \\
\pm 0.21\end{array}$ & 0.91 \\
\hline $8-12$ & $\begin{array}{l}10.72 \\
\pm 0.22\end{array}$ & $0-3$ & $\begin{array}{c}0.96 \\
\pm 0.13\end{array}$ & $0-2$ & $\begin{array}{c}0.12 \\
\pm 0.08\end{array}$ & $19-24$ & $\begin{array}{l}22.88 \\
\pm 0.26\end{array}$ & 0.99 \\
\hline $9-12$ & $\begin{array}{l}10.84 \\
\pm 0.15\end{array}$ & $0-3$ & $\begin{array}{c}1.0 \\
\pm 0.11\end{array}$ & $0-1$ & $\begin{array}{c}0.04 \\
\pm 0.08\end{array}$ & $20-24$ & $\begin{array}{l}23.4 \\
\pm 0.17\end{array}$ & 0.96 \\
\hline
\end{tabular}

distribution of chromosomes at anaphase I (A I) and pollen fertility. The details for hybrids are summarised in Tables 4 and 5 , whereas for parents that showed normal meiotic cycle elsewhere (Yadava \& SingH 1984).

Hybrids from crosses with C. dipsaceus as one of the parents showed a higher mean of univalents and lower mean of bivalents at $5 \%$ level of significance than the hybrids of rest of the species (Table 4; Figs. 1-3,6). The mean univalent number ranged from 4.86 in $C$. dipsaceus $\times C$. myriocarpus, to a minimum of 2.2 in $C$. prophetarum $\times C$. dipsaceus 
(Table 4). Whereas the hybrids, between the two varieties of $C$. anguria, and between $C$. anguria var. longipus and $C$. prophetarum have higher ring bivalent associations at $5 \%$ level of significance than others (Table 4).

The chromosome associations in other species hybrids were not significantly different from each other. $C$. myriocarpus hybrids with $C$. prophetarum and $C$. zeyheri have 11.0 and 11.66 bivalents respectively compared to 9.40 recorded for C. dipsaceus $\times$ C. myriocarpus (Table 4, Fig. 5).

In crosses involving $C$. prophetarum highest mean number of bivalents were observed in $C$. prophetarum $\times C$. zeyheri and C. prophetarum $\times$ accession CUCU 44/74 (Table 4). However the pollen fertility was less in the former $(23.07 \%)$ than the latter $(48.85 \%)$. In other crosses involving $C$. prophetarum and two varieties of $C$. anguria, the mean bivalent frequencies and pollen fertility were similar (Table 4, Fig. 4). However, the hybrid from reciprocal cross, C. anguria var. longipus $\times$ C. prophetarum showed near normal pairing and a high pollen fertility $(81.74 \%)$ (Tables 4 , 5). In C. myriocarpus $\times$ C. prophetarum the bivalent frequency was 11.0 with a pollen fertility of $21.6 \%$.

Both the ring and the rod bivalents were recorded. The frequency of rod bivalents was low with the mean ranging from 0.64 to 1.88 (Table 4). The mean chiasma frequency in the hybrids was not significantly different from parent species (YADAVA \& SINGH 1983). Chiasma frequency was maximum in the intraspecific cross of $C$. anguria and minimum in the hybrids involving $C$. dipsaceus as one of the parents (Table 4).

Majority of the hybrids showed multivalents but in a low frequency (Table 4; Figs. 1-8).

At AI hybrids often exhibited unequal distribution, laggards and chromosome bridges with or without fragments (Table 5; Figs. 9, 10). Chromosome bridge with a fragment was observed in 5 hybrid combinations, $C$. dipsaceus crossed with $C$. myriocarpus, $C$. zeyheri and $C$. anguria var. anguria, and in the crosses, between two varieties of $C$. anguria and C. prophetarum.

Figs. 1-10. Pollen mother cells at metaphase I in Cucumis species hybrids. - Fig. 1. $7 \mathrm{II}+2 \mathrm{III}+4 \mathrm{I}$ in $C$. dipsaceus $\times C$. anguria var. longipus. - Fig. 2 . $9 \mathrm{II}+1 \mathrm{IV}+21 .-$ Fig. $3.6 \mathrm{II}+2 \mathrm{III}+6 \mathrm{I}$, and - Fig. $4.8 \mathrm{II}+1 \mathrm{IV}+4 \mathrm{I}$ in $C$. prophetarum $\times C$. anguria var. anguria - Fig. $5.6 \mathrm{II}+1 \mathrm{IV}+8 \mathrm{I}$ in $C$. myriocarpus $\times$ C. prophetarum. - Fig. $6.8 \mathrm{II}+6 \mathrm{I}$ and - Fig. $7.6 \mathrm{II}+2 \mathrm{IV}+4 \mathrm{I}$ in C. dipsaceus $\times$ C. zeyheri. - Fig. 8. $5 \mathrm{II}+1 \mathrm{III}+11 \mathrm{I}$ in $C$. zeyheri $\times$ C. anguria var. anguria; (multivalents arrows). - Fig. 9. A lagging II, and - Fig. 10. Bridge with fragment (arrow) in C. prophetarum $\times$ C. anguria var. anguria 


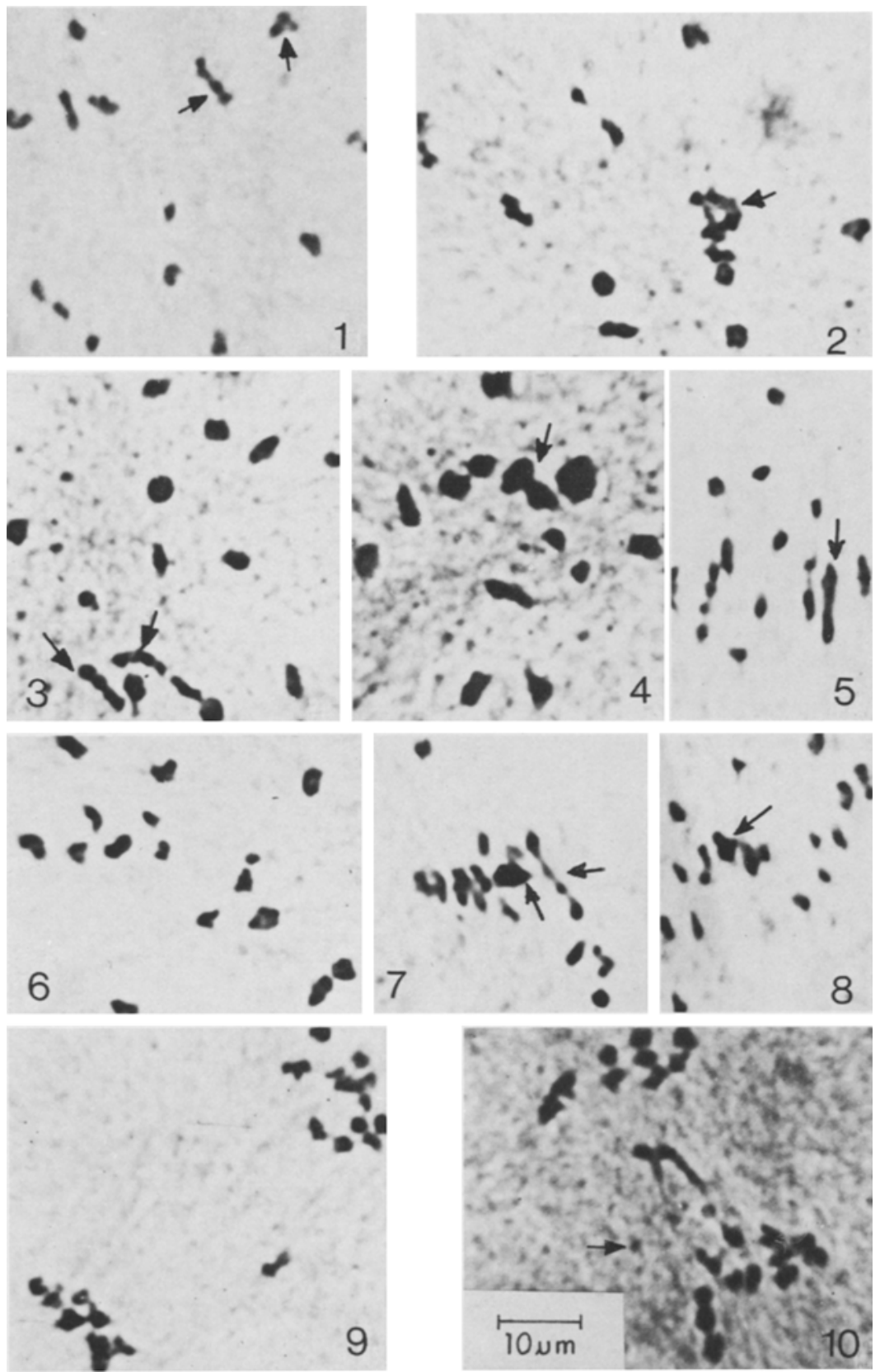


Table 5. Chromosome distribution at $\mathrm{AI}$ and pollen fertility in $\mathrm{F}_{1}$ hybrids of Cucumis species. Pollen fertility in parent species ranged from 86-98\%. * Combination with a chromosome bridge and fragment

\begin{tabular}{cccccc}
\hline Cross & $\%$ Cells with & $\%$ Cells with & $\%$ Cells & $\%$ Cells & Pollen \\
& regular & unequal & with & with & fertility \\
& distribution & distribution & laggards bridge(s) & $\%$
\end{tabular}

C. dipsaceus

C. dipsaceus $\times$ myriocarpus*

C. dipsaceus $\times$ anguria var.

longipus

C. dipsaceus $\times$ anguria var. anguria*

C. prophetarum $\times$ dipsaceus

C. prophetarum $\times$ zeyheri

C. prophetarum $\times \quad$ Coll.

CUCU 44/74

C. prophetarum $\times$ anguria var.

longipus*

40

32

24

32

40

48

40

24

C. prophetarum $\times$ anguria var.

anguria*

C. myriocarpus $\times$ prophetarum

C. zeyheri $\times$ myriocarpus

C. zeyheri $\times$ anguria var. longipus

C. anguria var. longipus $\times$ prophetarum

C. anguria var. longipus $\times$ anguria var. anguria C. anguria var. anguria $\times$ anguria var. longipus

72

48

40

32

88

60

60
34

34

28

25

10

32

36

32

20

8

19.71

10

14

16

79.60

28

20

$20 \quad 16.01$

5

7

0

81.74

$16 \quad 17.41$

$0 \quad 21.61$

$0 \quad 22.36$

20

40

6.01

10

0

0

$0 \quad 80.00$
0




\section{Discussion}

Cucumis comprises a large number of morphologically related, cross compatible and cross incompatible taxa. The wild species with $2 \mathrm{n}=24$ are mainly distributed in East and South Africa, whereas the cultivated species C. melo $(2 \mathrm{n}=24)$ is widspread in arid and semi-arid regions of Africa and Asia. As Cucurbits have been known for photoperiod and temperature sensitivity the relative crossability data obtained in the present investigation under natural conditions may not be accurate for tracing relative affinities between the species at microevolutionary level. However at higher level studies of DEAKIN \& al. (1971) did support morphological grouping of spiny fruited species into one, which are cross compatible with each other but cross incompatible with other non-spiny fruited species including the cultivated C. melo.

The species studied in the present investigation exhibited different degree of female cross compatibility. The species $C$. dipsaceus and $C$. prophetarum were found to be more compatible when used as female. Such differences are often associated with habit and ploidy, but in these species the former is an annual and the latter a perennial with similar ploidy levels; hence the differences in crossability (Table 2) may be because of different physiological, genetical or environmental factors.

The high degree of chromosome pairing observed in the hybrids of the presently investigated species, indicates genome homology. Based on karyotypic similarities, YADAVA \& SingH (1984) divided the 13 investigated Cucumis species $(2 \mathrm{n}=24)$ into 5 distinct groups. They are- $(1)$ C. leptodermis Schweik,, C. africanus LindLEY f.-(2) C. ficifolius A. Rich., C. hookeri NAUd., C. dipsaceus Ehrenb. ex SpaCH - (3) C. myriocarpus Naud., C. zeyheri Sond., C. prophetarum L. f., C. species CUCU 44/74, C. anguria L. - (4) C. metuliferus E. Mey. ex SCHRAd. - (5) C. sagittatus PeYr, C. melo L. Species of the third karyomorphological group, C. zeyheri, C. prophetarum, C. myriocarpus, accessions CUCU 44/74 and two varieties of $C$. anguria appear to have strong genomic affinities as evidenced by the chromosome associations in their $F_{1}$ hybrids which do not differ significantly from each other (Table 4,5 ). However, based on bivalent associations (11.04), which is an indicator of genetic homology and a high pollen fertility $(48.85 \%)$ in this group, $C$. prophetarum is very close to the newly investigated accession CUCU 44/74, although the homology between the respective pairs of chromosomes has reduced as evidenced by univalents (Table 4). The hybrids of $C$. prophetarum with other taxa, $C$. zeyheri, $C$. myriocarpus, $C$. anguria var. longipus and $C$. anguria var. anguria have almost identical bivalent and univalent associations (Table 4) but unlike above combinations, they show multivalents and lower pollen fertility. This suggests structural differences between the chromo- 
somes of $C$. prophetarum and these species. $C$. prophetarum may differ from $C$, anguria by an inversion as a bridge with fragment was observed at $\mathrm{A} I$ in a few PMCs of hybrids with both the varieties. Such differences may affect genetic segregation and pollen fertility in hybrids even after higher genomic homology between species. But the established reciprocal of $C$. anguria var. longipus $\times C$. prophetarum showed nearly normal bivalent association suppressing quadrivalent and A I abnormalities resulting in high pollen fertility $(81.74 \%)$, probably a cytoplasmic influence.

It may be noted that in most of these crosses pollen fertility is low even after high bivalent associations (Tables 4,5 ). This may be due to one or more of the following reasons - (1) structural differences between the chromosomes of parental species that are manifested as multivalent associations observed in majority of the hybrids but at a very low frequency, - (2) due to early terminalisation of chiasmata because of inadequate homology leading to non-coorientation of the participating chromosomes, and $-(3)$ as a result of cryptic structural differences between chromosomes resulting in genic imbalance and reduction of pollen fertility. Therefore genomic affinity as expressed by pairing may not be expressed in terms of pollen fertility of the hybrid.

Higher bivalent associations and pollen fertility of hybrids between $C$. anguria var. anguria and $C$. anguria var. longipus suggest their close relationship. Their next close relatives are $C$. prophetarum, and $C$. zeyheri (Table 4). However, C. zeyheri is a little distinct evidenced by a higher mean of univalents and very low pollen fertility (Tables 4, 5). Among the rest of the species, $C$. zeyheri and $C$. myriocarpus appear closer to each other than they are to $C$. prophetarum based on high bivalent and low univalent and multivalent associations in the hybrids of former species than the latter (Table 4), although pollen fertility was uniformly low in all combinations (Table 5).

The crossability between two varieties of $C$. anguria in both directions, normal chromosomal pairing and high pollen fertility in their hybrid are in agreement with the earlier conclusions of MEEUSE (1958), DEAKIN \& al. (1971) and DANE \& al. (1980) on their varietal status. The differences in crossability and significantly higher mean of ring bivalents in the hybrids of $C$. anguria var. longipus suggest that $C$. anguria var. longipus is closer to these species than $C$. anguria var. anguria (Table 2, 4).

$C$. dipsaceus which was placed in a different group on karyomorphological grounds, crossed with other species of the preceding group in one or the other direction. The hybrids between $C$. dipsaceus and other species have significantly less bivalents and more univalents and low pollen fertility (Table 4, 5). Mean bivalent associations and pollen fertility ranged from 9.4 and $13 \%$ respectively in case of $C$. dipsaceus $\times C$. myriocarpus to 10.56 and $26 \%$ in case of $C$. prophetarum $\times C$. dipsaceus. These values are 
less than those observed in intragroup hybrids of the previous group (Tables 4,5 ). Therefore, the phylogenetic affinities of $C$. dipsaceus with other species are of distant nature and hence, this taxon may be recognised as a member of another subgroup. Regarding relative phylogenetic relationships between $C$. dipsaceus and other species, based on chromosome pairing and pollen fertility of the hybrids, C. prophetarum is the closest with lowest mean univalent and highest pollen fertility followed by C. zeyheri, C. anguria and C. myriocarpus (Table 4, 5). Observation of a bridge with a fragment in 3 hybrid combinations of $C$. dipsaceus out of 5 (Table 5) suggests a difference by an inversion between these three species and $C$. dipsaceus.

The present cytological analysis also revealed some factors responsible for speciation. The multivalent association observed in a majority of hybrids (Table 4) suggest that chromosomal alteration such as translocation and inversion has been one of the factors responsible for species differentiation. However, the frequencies across different combinations were low and not significantly different from each other. At A I along with other abnormalities in 5 combinations, observation of a chromosome bridge with fragment and high pollen sterility suggest that the involved species probably differ by a paracentric inversion.

A comprehensive look at morphology, karyotype, crossability, chromosome pairing and pollen fertility in these hybrids suggests that $C$. dipsaceus, C. myriocarpus, C. zeyheri, C. prophetarum, accession CUCU 44/74, C. anguria var. longipus and C. anguria var. anguria are members of a single group with varying degrees of cytological divergence. However, C. dipsaceus, karyomorphologically, and based on chromosome pairing in its hybrids with other species stands distinct from the rest.

The success in crossing between some other species belonging to different karyomorphological groups and some species studied in present investigation have been reported by DANE \& al. (1980). DANE \& al. (1980) observed a similar level of pairing in hybrids of C. anguria $\times C$. africanus; C. myriocarpus $\times C$. leptodermis besides $C$. dipsaceus $\times C$. zeyheri and $C$. anguria $\times C$. dipsaceus indicating that these species although falling in different karyomorphological groups have close genomic affinities. But the high univalent formation in C. anguria $\times$ C. myriocarpus suggests that the two species are far differentiated, contrary to the karyomorphological observations of YADAVA \& SINGH (1984). On the other hand meiotic behaviour of $C$. ficifolius $\times C$. zeyheri hybrid with high univalent frequency is in agreement for their placement into two karyomorphological subgroups (YADAVA \& SINGH 1984). In brief, all these species should be recognised as members of one group, from the same gene pool containing primitive wild species, and are interfertile.

Hybridization between $C$. melo var. momordica, a widely adapted 
cultivated taxon of the Indian subcontinent and other wild species failed except in $C$. prophetarum $\times C$. melo var. momordica, where fruits with inviable seeds were obtained (Table 2). This is suggestive of reproductive isolation and/or separation of gene pools of cultivated C. melo and the wild spiny fruited species of Cucumis. From the biosystematic point of view, they should be regarded as members of distinct group. From the breeding point of view, the barriers between the species of these two groups appear to be postzygotic and may be overcome by the technique of embryo culture.

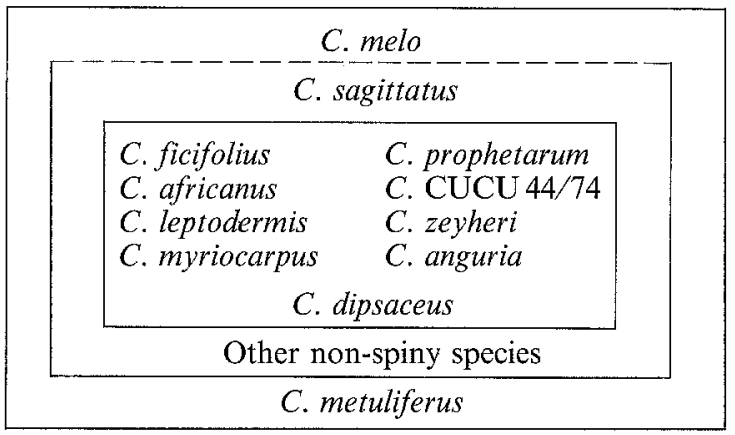

Species $2 n=24$
C. sativus

C. hardwickii

Fig. 11. Grouping by compatibility and chromosome pairing in Cucumis. Incompatible, - - - weak compatibility. $C$. ficifolius and $C$. dipsaceus are distinct by karyomorphology \& pairing in $\mathrm{F}_{1}$

Based on morphological similarity in fruit character and hybridization between $C$. sagittatus $\times$ C. melo yielding partly developed seeds DEAKIn \& al. (1971) kept the two species and other related non-spiny taxa together in a group. These two species failed to cross with spiny fruited species, indicating that they have evolved along a separate line diverging from spiny fruited species, and should be recognised as separate groups. It is also evidenced by karyomorphological studies of YADAVA \& SINGH (1984). However, C. metuliferus which was earlier recognised as the alone member of a separate group based on morphology and cross incompatibility between this species and other species (DEAKIN \& al. 1971) and also falls in a separate karyomorphological group (YADAVA \& SINGH 1984), have been reported to produce fertile hybrids with C. melo (NORTON 1969, NORTON \& GRANBERRY 1980) concluding that C. metuliferus is evolutionarily close to C. melo.

The picture that emerges from the foregoing discussion is the existence of three broad groups in Cucumis species with $2 \mathrm{n}=24$ (Fig. 11). The first 
group is of wild spiny fruited species distributed in different regions of Africa. They are interfertile, have common ancestry and can further be divided into subgroups based on karyomorphological similarities and chromosome pairing in their $F_{1}$ hybrids. Among these species based on karyomorphological symmetry (YADAVA \& SINGH 1984) and host-parasite relationship (LEPPIK 1966) the South African species are considered primitive. The second group is of the non-spiny fruited species which are cross incompatible with the spiny fruited species and hybridize with $C$. melo but rarely producing viable seeds. Therefore, according to HARLAN \& DE WET (1971) the non-spiny fruited wild species can be recognised as a group of species with secondary gene pool, while C. metuliferus, the cultivated species, $C$. melo and its varieties which are completely isolated from the primary gene pool of spiny fruited species and have weak compatibility with the second group, can be recognised as the third group. The fourth group of species with $C$. hardwickii and C. sativus, has a different base number $(x=7)$, origin and distribution (YADAVA \& SinGH 1984), and probably deviated at an early stage of evolutionary ladder from primary gene pool of spiny fruited species (Fig. 11).

Authors express their deep sense of gratitude to Prof. H. C. ARYA for providing necessary facilities. One of us (K. S. Y.) is thankful to ICAR, and CSIR for providing financial assistance.

\section{References}

Andrus, C. F.. Fassuliotis, G., 1965: Crosses among Cucumis species. - Veget. Improv. Newslett. 7, 3.

BAtra, S., 1953: Interspecific hybridization the genus Cucumis. - Sci. \& Cul. 18, $445-446$.

Brown, G. B., Deakin, J. R., Wood, M. B., 1969: Identification of Cucumis species by paper chromatography of flavonoids. - Soc. Hort. Sci. 94, 231-234.

Dane, F., Denna, D. W., Tsuchiya, T., 1980: Evolutionary studies of wild species in the genus Cucumis. - Z. Pflanzenzüchtung 85, 89-109.

Deakrn, J. R., Bohn, G. W. Whitaker, T. W., 1971; Interspecific hybridization in Cucumis. - Econ. Bot. 25, 195-211.

Harlan, J. R., DE WET, J. M. J., 1971: Towards a rational classification of cultivated plants. - Taxon 17, 109-240.

Imazu, T., Fujishita, N., 1956: Cucumbers. - Land and Crops of Nepal Himalaya 2, 213-228.

JefFery, C., 1980: A review of the Cucurbitaceae. - Bot. J. Linn. Soc. 81, $233-247$.

Kho, Y. O., Nuss, A. P. M. Den, Franken, J., 1980: Interspecific hybridization in Cucumis L. II. The crossability of species, an investigation of in vivo pollen tube growth and seed set. - Euphytica 29, 661-672.

Kroon, G. H., Custers, J. B. M., Kho, Y. O., NiJs, A. P. M. Den, Varekamp, H. Q., 1979: Interspecific hybridization in Cucumis L. 1. Need for genetic variation, biosystematic relations and possibilities to overcome crossability barriers. Euphytica 28, 723-728. 
LEPPIK, E. E., 1966: Searching gene centres of the genus Cucumis through host parasite relationship. - Euphytica 1, 323-328.

Meeuse, A. D. J., 1958: The possible origin of Cucumis anguria L. - Blumea Suppl. 4, 196-204.

Norton, J. D., 1969: Incorporation of resistance to Meloidogyne incognita acrita into Cucumis melo. - Proc. Ass. Southern Agri. Workers 66th Ann. Conf., 212.

- Granberry, D. M., 1980: Characteristics of progeny from an interspecific cross of Cucumis melo with C. metuliferus. - J. Amer. Soc. Hort. Sci. 105, $174-180$.

Nus, A. P. M. Den, Oost, E. H., 1980: Effect of mentor pollen on pistil-pollen incogruities among species of Cucumis L. - Euphytica 29, 267-271.

ReHm, S., 1960: Die Bitterstoffe der Cucurbitaceen. - Erg. Biol. 22, 108-136.

Smith, P. G., Venkat Ram, B. R., 1954: Interspecific hybridization between muskmelon and cucumber. - J. Hered. 45, 24.

Whitaker, T. W., 1933: Cytological and phylogenetic studies in Cucurbitaceae.Bot. Gaz. 94, 780- 790.

Yadava, K. S., Singh, A. K., Arya, H. C., 1984: Cytogenetics in Cucumis L. I. Meiotic analysis in twenty four Cucumis species. - Cytologia 49, 1-9.

- - 1984: Cytogenetics in Cucumis. II. Karyotypic evolution. - In Rosinson, R. W., (Ed.): Biology and Chemistry of Cucurbitaceae (in press).

Addresses of the authors: A. K. SINGH, Groundnut Program, ICRISAT, Patancheru P.O. 502324 , A.P., India. - K. S. YADAva, Department of Botany, University of Jodhpur, Jodhpur 342001, India. 